Dept. of Animal Medicine (Infectious Diseases),

Fac. of Vet. Med., Kafrelsheikh University, Kafrelsheikh 33516, Egypt.

\title{
A SEROLOGICAL INVESTIGATION OF CAPRINE ARTHRITIS ENCEPHALITIS VIRUS (CAEV) IN GOATS BY COMPETITIVE ELISA AT KAFRELSHEIKH GOVERNORATE, EGYPT
}

(With One Table and 3 Figures)

\author{
By \\ Y. MOHAMED ABDEL RAHMAN GHANEM \\ (Received at 7/6/2011)
}
دراسة سيرولوجية لمرض التهاب المفاصل والأعصاب باستخدام اختبار الاليزا التنافسية بمحافظة كفر الثيخ والأبن$$
\text { ياسسر محمد عبل الرحمن غانم }
$$

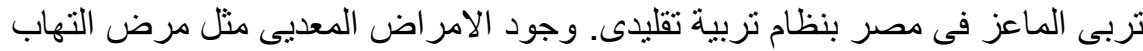

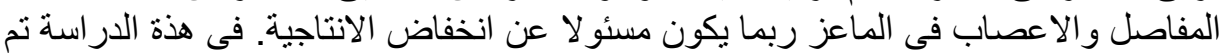

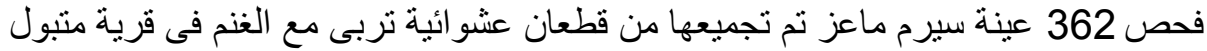

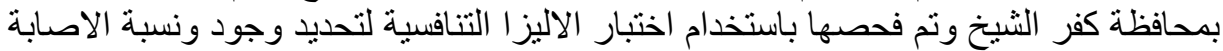

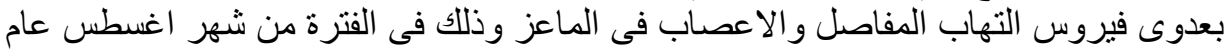

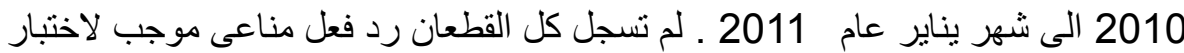

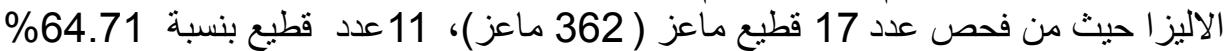

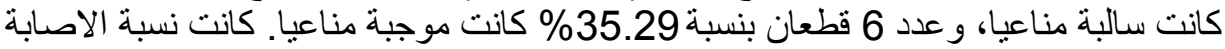

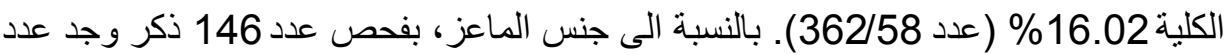

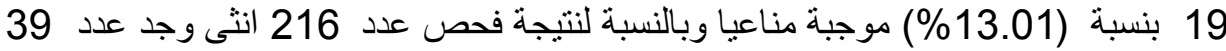

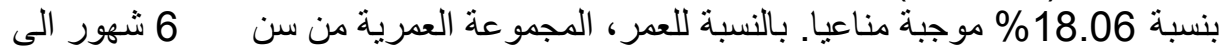

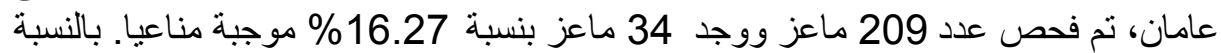

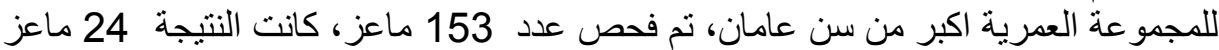

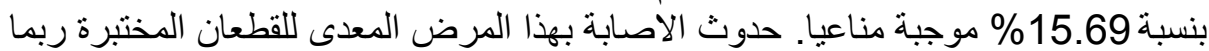

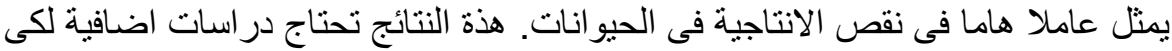

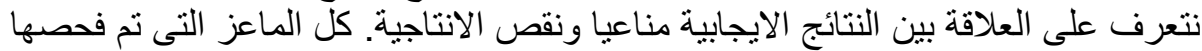

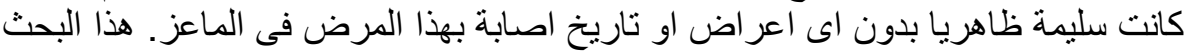

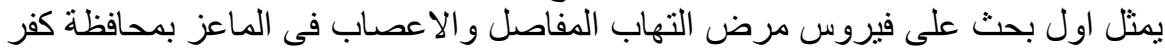
الثيخ بجمهورية مصر العربية. 


\section{SUMMARY}

Goats in Egypt are kept under traditional management system. The occurrence of infectious diseases, such caprine arthritis-encephalitis (CAE) may in part be responsible for sub-optimal production. In the present study, 362 serum samples were collected from randomly distributed goat herds reared with sheep from Matbool village of Kafrelsheikh Governorate and examined using competitive enzyme linked immunosorbent assay (cELISA) to determine the existence and prevalence CAEV infection from the period of August 2010 to January 2011. Not all tested flocks presented seroreactive animals for CAEV, Out of 17 goat/herds investigated (362 goats), 11 herd/flocks (64.71\%) were seronegative and 6 herd/flocks $(35.29 \%)$ were seropositive with overall seroprevalence $16.02 \%(n=58 / 362)$. According to sex, out of 146 males tested $19(13.01 \%)$ were seropositive and out of 216 females tested, $39(18.06 \%)$ were seropositive. According to age, for age group from 6 month-2 years old, 209 goats were tested and 34 (16.27\%) were seropositive, while for age group over 2 years old, 153 were tested and $24(15.69 \%)$ were seropositive. The occurrence of this infectious disease in the tested flocks may represent an important factor contributing to the decreased productivity of the animals. These findings require further study to define the relationship between seropositivity and reduced production. All goats tested were apparently normal without showing clinical signs and without history of any specific clinical signs for CAE viral infection. This is the first research on CAEV in goats at Kafrelsheikh governorate, Egypt.

Key words: Caprine arthritis-encephalitis, CAE, Goats, Competitive-ELISA

\section{INTRODUCTION}

According to Devendra (1990), approximately $95 \%$ of all goats world-wide are located in developing countries. Nearly all caprine and ovine are raised by traditional methods of husbandry in small herd/flocks with or without other species in small settlements with restricted movements except for grazing or water sources.

No reports as far as we know are available on the prevalence of CAEV infection among goat populations at Kafrelsheikh Governorate (Egypt) to determine the distribution of the disease. 
Caprine arthritis-encephalitis (CAE) virus is one of only two lentiviruses belongs to the Retroviridae family, that currently are known to infect sheep and goats (Pugh, 2002); Rowe and East (1997). CAEV is genetically and antigenically related to visna-maedi virus (MVV) of sheep (Ravazzolo et al., 2001). CAE can affect goats of both sexes, of various different races, and at all ages. However, encephalitis occurs more frequently in young animals, while arthritis in more mature animals (Callado et al., 2001).

Countries with the highest prevalence of CAEV infection include the United States, France, Norway, Switzerland, and Canada (Smith, and Sherman, 1994). It has been diagnosed in North America, Europe, Kenya, Peru, Australia, and New Zealand (Knight and Jokinen, 1982; Pugh, 2002; Smith and Sherman, 1994). The results from Kenya and Mexico showed that 4-5\% of the goats were infected (Adams et al., 1984), higher seroprevalence rates were recorded in the USA (Cutlip et al., 1992) and Australia (Grewal et al., 1986), where intensive husbandry is generally practiced.

The development of clinical disease takes a few months to a few years, however, most infected animals remained subclinically infected (Cheevers et al., 1988). Most goats infected with CAE virus are asymptomatic, but there are five major clinical presentations associated with viral infection including arthritis, encephalitis, interstitial pneumonia, mastitis, and progressive weight loss (Matthews, 1999; Smith and Sherman 1994; Van Maanen et al. 2010).

The virus is transmitted to kids primarily via colostrum, although transmission via aerosol, animal-to-animal contact, and sexual activity can also occur (Phelps and Smith, 1993; Rowe and East, 1997; Peterhans et al., 2004). Other clinical presentations can include a hard udder or mastitis which greatly diminishes the milk production (Narayan and Clements, 1989; Callado et al., 2001; Leitner et al., 2010). Horizontal transmission is possible by prolonged contact with infected goats via shedding of the virus in the saliva, the urogenital secretions, and the feces (Rowe and East, 1997). Contact with the blood of an infected animal can also transmit the disease (Matthews, 1999). Other potential sources of viral transmission include viral contamination of milking equipment, needles, tattooing equipment; and breeding an infected animal with a non-infected animal (Adams et al., 1983).

Despite humoral and cellular immunity, CAEV causes a lifetime infection and infected goats serve as a reservoir of the virus for the entire lives (Adams et al., 1980; Dawson, 1989). Infected goats are carriers 
without showing clinical signs and delayed seroconversion are impediment in control and eradication programs (Rowe et al., 1992; Rimstad et al., 1993). Some reports confirmed that the serological methods are not sufficient enough to detect all infected animals which could be attributed to longtime seroconversion after infection (Rimstad et al., 1993) or to the fact that some already infected goats may become temporary seronegative (Harkiss and Watt, 1990). It is also important to note that the maternal antibodies passed in the colostrum are not protective for kids ingesting the colostrum (Adams et al., 1983).

Therefore, the presence of antibodies indicates that the animal is infected with CAE virus (Knowles, 1997). The gold standard in testing for CAE antibodies is the immunoprecipitation assay (IP), but it is too expensive to use as a common diagnostic tool. There is a competitive ELISA (cELISA) that has just been developed to detect serum antibodies to CAE. The cELISA is more sensitive than the IP test in detecting CAE antibodies. The cELISA can evaluate undiluted serum, thus detecting lower titers of anti-CAE antibody than the indirect ELISAs. This feature may possibly allow for the earlier detection of CAE positive animals. Validation of this CAEV cELISA for use in sheep was reported previously (Herrmann et al., 2003). Recommendation of several authors, who stated that ELISA is a more reliable test due to its higher sensitivity (Rosati et al., 1994; Castro et al., 1999).

The aim of this work is to detect the possible occurrence of CAEV in goats and to analyse the epidemiological status with the presence of specific antibodies using cELISA.

\section{MATERIALS and METHODS}

\section{1- Area}

The present study was conducted during the period from August 2010 to January 2011 at Matbool village of Kafrelsheikh Governorate, Egypt.

\section{2- Animals}

Data from sporadic herds comprising 362 goats of both sexes of different age groups (6 month -6 years) were collected and analysed for CAEV. Flocks were chosen randomly and samples were collected from each herd (All herds goats reared with sheep). At the time of sample collection, no information on the history of each goat was provided to avoid sampling bias. The number of goat heads per herd/flock range between 12-33. Goats sera were collected as 146 males and 216 females. 


\section{3- Clinical Examination}

Goats were examined for encephalitis, mastitis and arthritis, which could suggest the infection. All tested animals did not show any apparent clinical signs of CAE.

\section{4- Sample collecting}

ten ml blood samples were collected from each goat from jugular vein using vacutainer tubes with a separate needle for each sample, allowed to clot, and transferred onto ice as quickly as possible to the Central Laboratory of Faculty of Veterinary Medicine, Kafrelsheikh University. The sera were separated by centrifugation at $2000 \mathrm{rpm}$ for 10 min: and aspirated in eppendorf tubes using Pasteur Pipettes, identified and stored at $-20^{\circ} \mathrm{C}$ until testing

5- Serological test (Laboratory assay procedures)

Serum samples were examined for specific antibodies using a commercially available Competitive ELISA (cELISA). VMRD, Inc. PO Box 502. Pullman, WA 99163 USA Phone: 1-509-334-5815. VMRD 's cELISA detect antibodies to caprine arthritis encephalitis virus (CAEV) in goat sera. The test is, however, only qualitative and so antibody titres were not measured.

\section{Test Procedure}

All reagents were stored at $2-7^{\circ} \mathrm{C}\left(35-45^{\circ} \mathrm{F}\right)$. Warm up reagents by bringing the serum samples, reagents and plate(s) to room temperature at least 30 min prior to starting the test. Remove the plate(s) from the foil pouch(es). Place strips to be used in the frame and number the top of each strip to maintain orientation with the Setup Record. Run both the Positive Control (B) and Negative Control (C) in duplicate. Load controls and serum samples using a pipettor set at $50 \mu \mathrm{l}$, transfer controls and serum samples to the Antigen-Coated Plate. Serum samples are tested undiluted. Tap the side of the loaded assay plate several times to make sure the samples coat the bottom of the wells. Incubate the plate 1 hour at room temperature $\left(21-25^{\circ} \mathrm{C}\right),\left(70-77^{\circ} \mathrm{F}\right)$. Prepare $1 \mathrm{X}$ Wash Solution by diluting one part of the $10 \mathrm{X}$ Wash Solution Concentrate $(\mathrm{F})$ with 9 parts of deionized or distilled water. Approximately $1.5 \mathrm{ml}$ are needed per well. After the 1-hour incubation, wash the plate three times and dump contents of the wells into a sink and remove the remaining sera and controls by sharply striking the inverted plate four times on a clean paper towel, striking a clean area each time. Immediately fill each well with $1 \mathrm{X}$ Wash Solution using repeating syringe with a manifold, wash bottle or multichannel pipettor. Dump out the Wash Solution and strike the inverted plate sharply on a clean paper towel as above. Repeat 
the washing procedure two more times (three washes total). Prepare $1 \mathrm{X}$ Antibody-Peroxidase Conjugate by diluting one part of the 100X Antibody-Peroxidase Conjugate (D) with 99 parts of Conjugate Diluting buffer (E). For 96 wells, mix $60 \mu$ of Antibody-Peroxidase Conjugate (D) with $5.940 \mathrm{ml}$ of Conjugate Diluting Buffer (E) to yield $6 \mathrm{ml}$ of ready-to-use Antibody-Peroxidase Conjugate. Fifty microliters $(50 \mu 1)$ are needed per well. Tap the side of the loaded assay plate several times to make sure the conjugate coats the bottom of the wells. Incubate for an additional 30 minutes at room temperature $\left(21-25^{\circ} \mathrm{C}, 70-77^{\circ} \mathrm{F}\right)$. After the 30 -minute incubation, repeat the washing procedure described before (3 washes total). Add $50 \mu \mathrm{l}$ of Substrate Solution (G) to each well. Tap the side of the loaded assay plate several times to make sure the substrate coats the bottom of the wells. Incubate 20 minutes at room temperature $\left(21-25^{\circ} \mathrm{C} ; 70-77^{\circ} \mathrm{F}\right)$. Do not empty wells. Add $50 \mu \mathrm{l}$ of Stop Solution $(\mathrm{H})$ to each well. Gently mix the well contents by tapping the side of the plate several times. Do not empty wells. Immediately after adding the Stop Solution, the plate should be read on a plate reader. Set the optical density (O.D.) reading wavelength to 620,630 or $650 \mathrm{~nm}$. Test Validation: The mean of the Negative Controls must produce an optical density $\geq 0.300$. The mean of the Positive Controls must produce $\geq 35 \%$ inhibition. Calculation of percent inhibition (\% I): \% I $=100$ [(Sample O.D. x 100) $\div$ (Mean Negative Control O.D.)]. Interpreting the Results: If a test sample produces $\geq 35 \%$ inhibition, it is positive. If a test sample produces $<35 \%$ inhibition, it is negative.

\section{RESULTS}

\section{Overall results}

Out of 17 goat/herds investigated (362 goats), 11 herd/flocks $(64.71 \%)$ were seronegative and 6 herd/flocks (35.29\%) were seropositive with overall seroprevalence $16.02 \%(n=58 / 362)$. According to sex, out of 146 males tested 19 (13.01\%) were seropositive and out of 216 females tested, 39 (18.06\%) were seropositive. According to age, for age group from 1-2 years old, 209 goats were tested and 34 (16.27\%) were seropositive while for age group over 2 years old, 153 were tested and $24(15.69 \%)$ were seropositive.All goats were apparently normal without showing clinical signs and without history of any specific clinical signs for CAE vial infection (Table 1). 
Assiut Vet. Med. J. Vol. 57 No. 130 July 2011

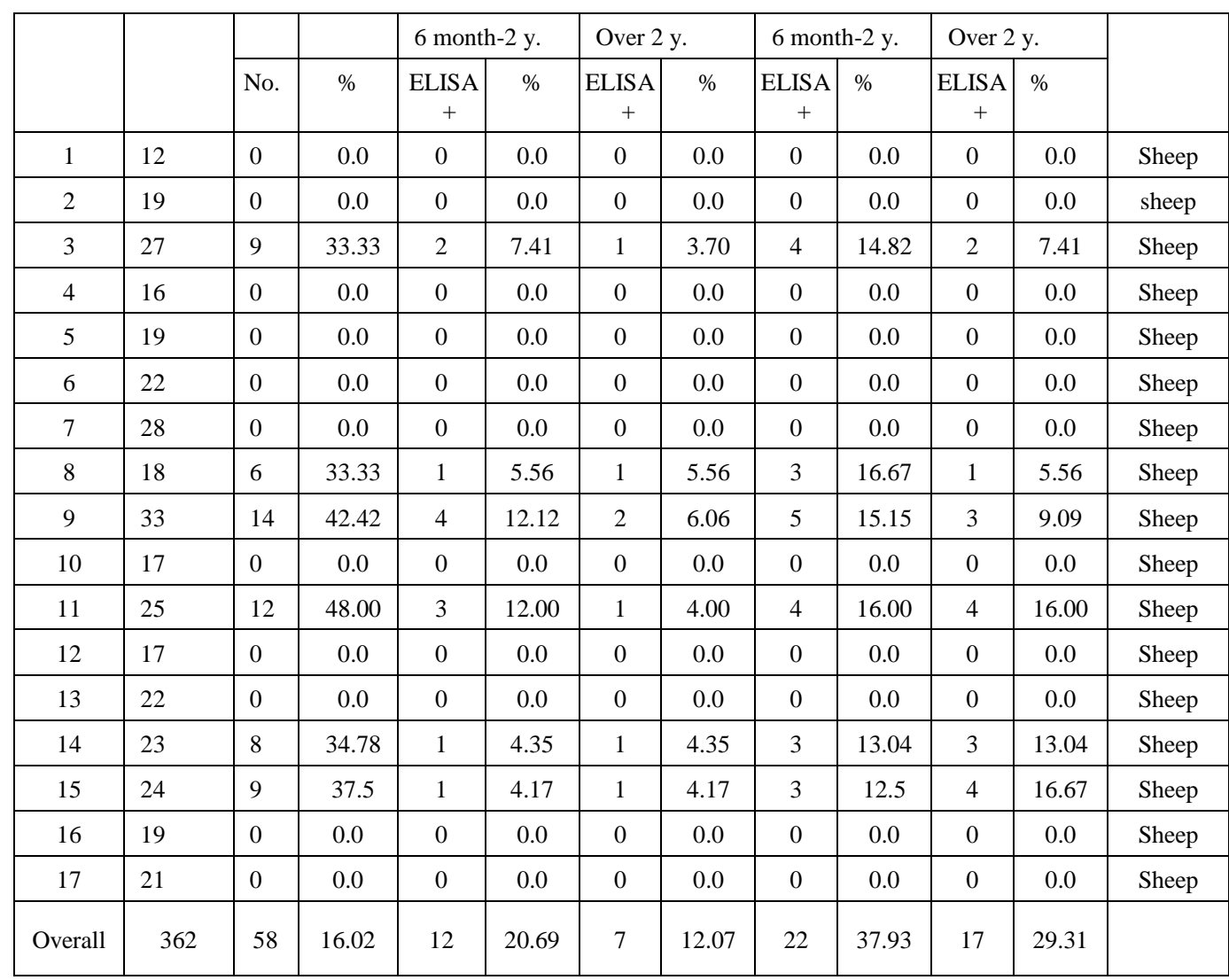

Table 1: Seroprevalence results of CAE ELISA positive goats from 17 herds at Matbool village of Kafrelsheikh governorate, Egypt. 
Assiut Vet. Med. J. Vol. 57 No. 130 July 2011

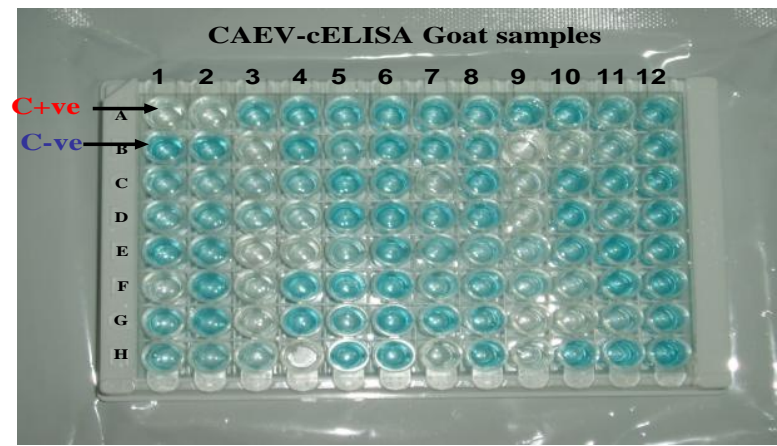




\section{CAEV-cELISA Goat samples}

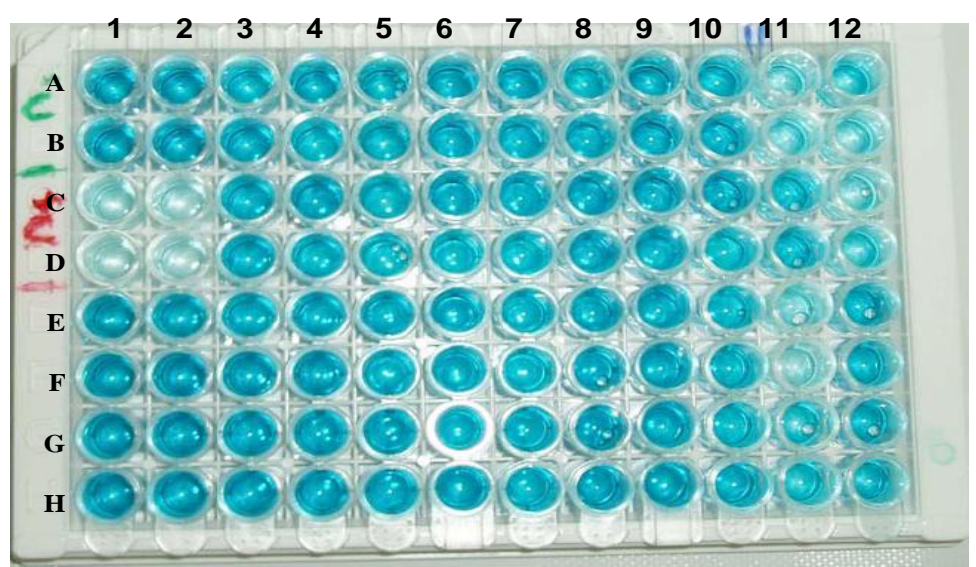

\section{CAEV-cELISA Goat samples}

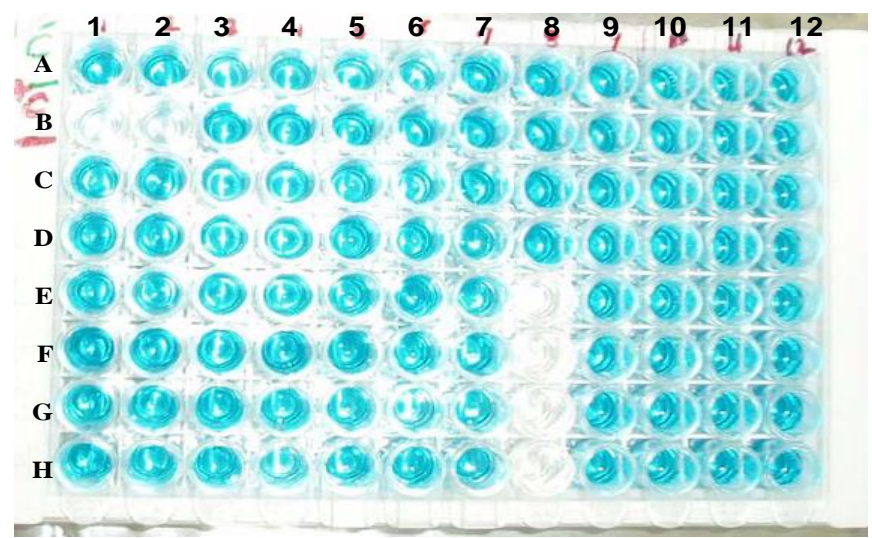

Competitive ELISA plates showing deep blue color negative wells and faint color seronegative wells. 


\section{DISCUSSION}

Most indirect ELISA systems presently in use lack specificity to varying degrees. VMRD's competitive ELISA assay for CAEV antibody detection eliminates most of these non-specific reactions. The cELISA is a well documented method for the detection of CAEV infection (Herrmann et al., 2003). Diagnosis of CAEV infection is based on the specific antibody detection (Castro et al., 1983; Zanoni et al., 1994; Keen et al., 1995; Knowles, 1997; Resende and Gouveia, 1999). Sensitivity and specificity of the cELISA against IP were $100 \%$ and $96.4 \%$, respectively. Sensitivity and specifity of AGIDT have been shown to be $92.6 \%$ and $98.6 \%$, respectively, cELISA detects CAEV antibodies and it is based on the serum inhibition of the monoclonal antibody binding to the CAEV gp135 SU glycoprotein. The ability to detect positive sera with low anti-CAEV gp135 SU antibody titres is a major advantage of the cELISA over indirect ELISA, which requires the dilution of the tested sera (Herrmann et al., 2003).

Overall seroprevalence of CAEV infection in this study was $16.02 \%$. The detection of seropositive serum samples with cELISA could be explained by the higher sensitivity of cELISA. Although seroreactivity to an organism does not translate into verification that the animal was clinically affected by that organism, the infectious diseases CAEV seem to be existed amongst goat flocks from Kafrelsheikh governorate and probably represents an important factor that may contributes to the decreased productivity of goats. The seroreactivity rates to CAEV were extremely variable among the studied 17 herds which ranged from $0.0 \%-48.0 \%$. Nevertheless, the overall reactivity of $16.02 \%$ is significant. We believe that those infections need more attention and a more intensive diagnostic programme is desirable. We believe that the seroprevalence noted in this study may be similar to that observed in many other regions and possibly elsewhere in the developing world. In this study, the seroprevalence of CAEV infection was detected with cELISA is higher than those found in UK $4.3 \%$ (Dawson and Wilesmith, 1985), Switzerland 2\% (Krieg and Peterhans, 1990) and lower than serosurveys conducted in Australia (Grewal et al., 1986), USA (Cutlip et al., 1992), Norway (Nord et al., 1998) and Brazil (Garcia et al., 1992), have revealed prevalence rates of $82 \%, 73 \%$, $49.5 \%$, and $36.5 \%$, respectively. 
Disease control worldwide were reported by many authors as prevention of CAE viral infection is important in goat herd management because there is no treatment that eliminates CAE virus or vaccine to prevent this disease. Seropositive animals should be segregated and culled and goats should only be purchased from CAE virus-free herds (Knight and Jokinen, 1982; Rowe et al., 1992; Linklater and Smith, 1993; Rowe and East, 1997; Matthews, 1999; Pugh, 2002). Correlation between CAEV infection, and breed, age and breeding methods has been reported (East et al., 1987; Cutlip et al., 1992; Randall et al., 1992; Nord et al., 1998).

However, in this study, the numbers of seropositive animals were insufficient to achieve any meaningful statistical conclusions. More herds must be investigated over a longer time, and additional managemental, environmental risk factors should be investigated using different methods such as cELISA may be required to assess the true distribution of CAEV in Kafrelsheikh governorate and allover the country. Furthermore, continuous monitoring should be carried out for local goat populations in Kafrelsheikh governorate and trials for virus isolation and molecular characterization should be carried out for future work.

\section{REFERENCES}

Adams, D.S.; Crawford, T.B.; Banks, K.L.; McGuine, T.C. and Perrymon, L.E. (1980): Immune responses of goats persistently infected with caprine arthritis-encephalitis virus. Infect. Immun., 28: 421-427.

Adams, D.S.; Klevjer-Anderson, P.; Carlson, J.L.; Mcguire, T.C. and Gorham, J.R. (1983): Transmission and control of caprine arthritis encephalitis virus. Am. J. Vet. Res., 44: 1670-75.

Adams, D.S.; Oliver, R.E.; Ameghini, E.; DeMartini, J.C.; Verwoerd, D. W.; Houwers, D.J.; Waghela, S.; Gorham, J.R.; Hyllseth, B.; Dawson, M.; Trigo, F.J. and McGuire, C. (1984): Global survey of serological evidence of caprine arthritis-encephalitis virus infection. Vet. Rec., 115: 493-4951.

Callado, A.K.C.; Castro, R.S. and Teixeira, M.F.S. (2001): Lentiviruses of small ruminants (CAEV e Maedi-Visna): a review and perspectives. Pesq. Vet. Bras. 21(3): 87-97.

Castro, R.S.; Leite, R.C.; Adams, D.S.; Klevjer-Anderson, P.; Carlson, B.S.; and McGuire, T.C. (1983): Transmission and control of 
caprine arthritis- encephalitis virus. Am. J. Vet. Res., 44: 1670-1675.

Castro, R.S.; Leite, R.C.; Resende, M. and Gouveia, A.M. (1999): A labelled avidinbiotin ELISA to detect antibodies to caprine arthritis-encephalitis virus in goats' sera. Vet. Res. Commun., 23(8): 515-22.

Cheevers, W.P.; Knowles, D. and McGuire, T.C. (1988): Cunningham D.: Chronic disease in goats orally infected with two isolates of caprine arthritis encephalitis lentivirus. Lab. Invest., 58: 510-517.

Cutlip, R.C.; Lehmkuhl, H.D.; Sacks, J.M. and Weaver, A.L. (1992): Prevalence of antibody to caprine arthritis-encephalitis virus in goats in the United States. J. Am. Vet. Med. Assoc., 200: 802-805.

Dawson, M. (1989): The caprine arthritis-encephalitis syndrome. Vet. Annu., 1989, 29: 98-102.

Dawson, M. and Wilesmith, J.W. (1985): Serological survey of lentivirus (maedi visna/caprine arthritis encephalitis) infection in British goat herds. Vet. Rec., 117: 86-89.

Devendra, C.D. (1990): Milk and kid production from dairy goats in developing countries. In: International Dairy Congress, 23, 1990, Montreal. Proceedings. Montreal, pp. 327-351.

East, N.E.; Rowe, J.D.; Madwell, B.R. and Floyd, K. (1987): Serologic prevalence of caprine arthritis-encephalitis virus in California goatdairies. J. Am. Vet. Med. Assoc., 190: 182-186.

Garcia, M.; Galhardo, M.; Araujo, W.P.; D'Angelino, J.L.; Bastos, P.S. and Rossini, A.J. (1992): Caprine arthritis-encephalitis (CAE) occurence of positive sera in goats raised in Brazil. Trop. Anim. Hlth. Prod., 24, 164.

Grewal, A.S.; Greenwood, P.E.; Burton, R.W.; Smith, J.E.; Batty, E.M. and North, R. (1986): Caprine retrovirus infection in New South Wales: virus isolations, clinical and histopathological findings and prevalence of antibody. Aust. Vet. J. 63: 245-248.

Grewal, A.S.; Littlejohns, I. and Smith, J. (1986): Two distinct gel diffusion precipitin tests for the diagnosis of retrovirus infection in goats. Aust. Vet. J., 63: 86-88.

Harkiss, G. and Watt, N. (1990): Lentivirus infections and their detection. Goat Vet. Soc. J., 11: 19-25.

Herrmann, L.M.; Cheevers, W.P.; McGuire, T.C.; Adams, D.S.; Hutton, M.M.; Gavin, W.G. and Knowles, D.P. (2003): Detection of 
serum antibodies to ovine progressive pneumonia virus in sheep by using a caprine arthritis encephalitis virus competitive-inhibition enzyme-linked immunosorbent assay. Clin. Diagn. Lab. Immunol. 10:862-865.

Keen, J.; Kwang, J. and Rosati, S. (1995): Comparison of ovine lentivirus detection by conventional and recombinant serological methods. Vet. Immunol. Immunopathol., 47: 295-309.

Knight, A.P. and Jokinen, M.P. (1982): Caprine arthritis-encephalitis. Compend Cont. Educ. Pract. Vet., 4: S263-S269.

Knowles, D.P. (1997): Laboratory diagnostic tests for retrovirus infections of small ruminants. Vet Clin N Am Food Anim Pract, 13: 1-11.

Krieg, A. and Peterhans, E. (1990): Caprine arthritis-encephalitis in Switzerland: epidemiological and clinical studies. Schweiz. Arch. Tierheilkd., 132: 345-352.

Leitner, G.; Krifucks, O.; Weisblit, L.; Lavi, Y.; Bernstein, S. and Merin, $U$. (2010): The effect of caprine arthritis encephalitis virus infection on production in goats. The Veterinary Journal, 183: 328-331.

Linklater, K.A. and Smith, M.C. (1993): Color Atlas of Diseases and Disorders of the Sheep and Goat. Wolfe Publishing, Aylesbury, England, , pp. 73-74, 97, 105: 139-140.

Matthews, J.G. (1999): Diseases of the Goat, $2^{\text {nd }}$ ed. Blackwell Science, Chelmsford, UK, , pp. 80-87.

Narayan, O. and Clements, J.E. (1989): Biology and pathogenesis of Lentiviruses. J. Gen. Virol., 70: 1617-1639.

Nord, K.; Loken, T. and Orten, A. (1998): Control of caprine arthritisencephalitis virus infection in three Norwegian goat herds. Small Rum. Res., 28: 109-114.

Peterhans, E.; Greenland, T.; Badiola, J.; Harkiss, G. Bertoni, G. Amorena, B.; Eliaszewicz, M.; Juste, R.A.; Krassnig, R.; Lafont, J.P.; Lenihan, P.; Petursson, G.; Pritchard, G.; Thorley, J.; Vitu, C.; Mornex, J.F. and Pepin, M. (2004): Routes of transmission and consequences of small ruminant lentiviruses (SRLVs) infection and eradication schemes. Veterinary Research; 35: 257-274.

Phelps, S.L. and Smith, M.C. (1993): Caprine arthritis encephalitis virus infection. J. Am. Vet. Med. Ass., 203(12): 1663-6. 
Pugh, D.G. (2002): Sheep and Goat Medicine. W.B. Saunders Company, Philadelphia, , pp. 126, 239-240, 296, 388.

Randall, C.; Cutlip, D.V.M.; Howard, D.; Lehmkuhl, P.; Jerorne, M.; Sacks, P.; Amy, L. and Weaver, M.S. (1992): Prevalence of antibody to caprine arthritis- encephalitis virus in goats in the United States. J. Am. Vet. Med. Assoc., 200: 802-805.

Ravazzolo, A.P.; Reischak, D.; Peterhans, E. and Zanoni, R. (2001): Phylogenetic analysis of small lentiviruses from Southern Brazil. Virus Res., 79: 117-123.

Resende, M. and Gouveia, A.M.G. (1999): A labelled avidin-biotin ELISA to detect antibodies to caprine arhritis-encephalitis virus in goats'sera. Vet. Res. Commun., 23: 515-522.

Rimstad, E.; East, N.E.; Torten, M.; Higgins, B.S.; DeRock, E. and Pedersen, N.C. (1993): Delayed seroconversion following naturally acquired caprine arthritis-encephalitis virus infection in goats. Am. J. Vet. Res., 54: 1858-1862.

Rosati, S.; Kwang, J.; Tolari, F. and Keen, J. (1994): A comparison of whole virus and recombinant transmembrane ELISA and immunodiffusion for detection of ovine lentivirus antibodies in Italian sheep flocks. Vet. Res. Commun., 18(1): 73-80.

Rowe, J.D. and East, N.E. (1997): Risk factors for transmission and methods for control of caprine arthritis-encephalitis virus infection. Vet Clin N Am Food Anim Pract,13: 33-53.

Rowe, J.D.; East, N.E.; Franti, C.E.; Thurmond, M.C.; Pedersen, N.C.; and Theilen, G.H. (1992): Risk factors associated with the incidence of seroconversion to caprine arthritis-encephalitis virus in goats on California dairies. Am. J. Vet. Res., 53: 2396-2403.

Smith, M.C. and Sherman, D.M. (1994): Goat Medicine. Lea \& Febiger, Philadelphia, pp. 73-79: 135-138.

Van Maanen, C.; Brinkhof, J.M.; Moll, L.; Colenbrander, B. and Houwers, D.J. (2010): Aspects of the epidemiology, research, and control of lentiviral infections of small ruminants and their relevance to Dutch sheep and goat farming. Tijdschr Diergeneeskd. 15, 135(16): 600-3.

Zanoni, R.G.; Vogt, H.R.; Pohl, B.; Bottcher, J.; Bommeli, W. and Peterhans, E. (1994): An ELISA based on whole virus for the detection of antibodies to small-ruminant lentiviruses. J. Vet. Med. B., 41: 662-669. 
Assiut Vet. Med. J. Vol. 57 No. 130 July 2011

\begin{tabular}{|c|c|c|c|c|c|c|c|c|c|c|c|c|}
\hline \multirow{3}{*}{$\begin{array}{l}\text { Herd } \\
\text { No. }\end{array}$} & \multirow{3}{*}{$\begin{array}{l}\text { Herd } \\
\text { size }\end{array}$} & \multirow{3}{*}{$\begin{array}{l}\text { Total } \\
\text { No. }\end{array}$} & \multirow{3}{*}{ 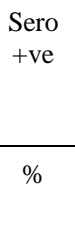 } & \multicolumn{4}{|c|}{ Male } & \multicolumn{4}{|c|}{ Female } & \multirow{3}{*}{$\begin{array}{l}\text { Contact } \\
\text { animals }\end{array}$} \\
\hline & & & & \multicolumn{2}{|c|}{6 month- $2 \mathrm{y}$. } & \multicolumn{2}{|c|}{ Over $2 \mathrm{y}$. } & \multicolumn{2}{|c|}{6 month-2 y. } & \multicolumn{2}{|c|}{ Over $2 \mathrm{y}$. } & \\
\hline & & & & $\begin{array}{c}\text { ELISA } \\
+\end{array}$ & $\%$ & $\begin{array}{c}\text { ELISA } \\
+\end{array}$ & $\%$ & $\begin{array}{c}\text { ELISA } \\
+\end{array}$ & $\%$ & $\begin{array}{c}\text { ELISA } \\
+\end{array}$ & $\%$ & \\
\hline 1 & 12 & 0 & 0.0 & 0 & 0.0 & 0 & 0.0 & 0 & 0.0 & 0 & 0.0 & Sheep \\
\hline 2 & 19 & 0 & 0.0 & 0 & 0.0 & 0 & 0.0 & 0 & 0.0 & 0 & 0.0 & sheep \\
\hline 3 & 27 & 9 & 33.33 & 2 & 7.41 & 1 & 3.70 & 4 & 14.82 & 2 & 7.41 & Sheep \\
\hline 4 & 16 & 0 & 0.0 & 0 & 0.0 & 0 & 0.0 & 0 & 0.0 & 0 & 0.0 & Sheep \\
\hline 5 & 19 & 0 & 0.0 & 0 & 0.0 & 0 & 0.0 & 0 & 0.0 & 0 & 0.0 & Sheep \\
\hline 6 & 22 & 0 & 0.0 & 0 & 0.0 & 0 & 0.0 & 0 & 0.0 & 0 & 0.0 & Sheep \\
\hline 7 & 28 & 0 & 0.0 & 0 & 0.0 & 0 & 0.0 & 0 & 0.0 & 0 & 0.0 & Sheep \\
\hline 8 & 18 & 6 & 33.33 & 1 & 5.56 & 1 & 5.56 & 3 & 16.67 & 1 & 5.56 & Sheep \\
\hline 9 & 33 & 14 & 42.42 & 4 & 12.12 & 2 & 6.06 & 5 & 15.15 & 3 & 9.09 & Sheep \\
\hline 10 & 17 & 0 & 0.0 & 0 & 0.0 & 0 & 0.0 & 0 & 0.0 & 0 & 0.0 & Sheep \\
\hline 11 & 25 & 12 & 48.00 & 3 & 12.00 & 1 & 4.00 & 4 & 16.00 & 4 & 16.00 & Sheep \\
\hline 12 & 17 & 0 & 0.0 & 0 & 0.0 & 0 & 0.0 & 0 & 0.0 & 0 & 0.0 & Sheep \\
\hline 13 & 22 & 0 & 0.0 & 0 & 0.0 & 0 & 0.0 & 0 & 0.0 & 0 & 0.0 & Sheep \\
\hline 14 & 23 & 8 & 34.78 & 1 & 4.35 & 1 & 4.35 & 3 & 13.04 & 3 & 13.04 & Sheep \\
\hline 15 & 24 & 9 & 37.5 & 1 & 4.17 & 1 & 4.17 & 3 & 12.5 & 4 & 16.67 & Sheep \\
\hline 16 & 19 & 0 & 0.0 & 0 & 0.0 & 0 & 0.0 & 0 & 0.0 & 0 & 0.0 & Sheep \\
\hline 17 & 21 & 0 & 0.0 & 0 & 0.0 & 0 & 0.0 & 0 & 0.0 & 0 & 0.0 & sheep \\
\hline
\end{tabular}

